\title{
Correction to: Characteristics of high enjoyment teachers of mathematics in primary schools
}

James Russo ${ }^{1}$

Published online: 10 June 2021

(c) Mathematics Education Research Group of Australasia, Inc. 2021

\section{Correction to: Mathematics Education Research Journal https://doi.org/10.1007/s13394-021-00372-z}

The original version of this article unfortunately contained an error in Fig. 2. An updated figure image was sent via e-mail.

Publisher's Note Springer Nature remains neutral with regard to jurisdictional claims in published maps and institutional affiliations.

The original article can be found online at https://doi.org/10.1007/s13394-021-00372-z.

\section{James Russo}

james.russo@monash.edu

1 Faculty of Education, Monash University, Melbourne, Australia 